\title{
Visual Constructs OF JERUSALEM
}




\title{
CULTURAL ENCOUNTERS IN LATE ANTIQUITY AND THE MIDDLE AGES
}

\author{
General Editor \\ Yitzhak Hen, Ben-Gurion University of the Negev \\ Editorial Board \\ Angelo di Berardino, Augustinianum, Rome \\ Nora Berend, University of Cambridge \\ Leslie Brubaker, University of Birmingham \\ Christoph Cluse, Universität Trier \\ Rob Meens, Universiteit Utrecht \\ James Montgomery, University of Cambridge \\ Alan V. Murray, University of Leeds \\ Thomas F.X. Noble, University of Notre Dame \\ Miri Rubin, Queen Mary, University of London
}

\section{VOLUME 18}

Previously published volumes in this series are listed at the back of this book. 


\title{
Visual Constructs OF JERUSALEM
}

Edited by

\author{
Bianca Kühnel, Galit Noga-Banai, \\ and Hanna Vorholt
}

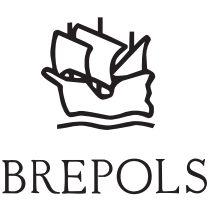


Visual constructs of Jerusalem. -- (Cultural encounters in late antiquity and the Middle Ages ; 18)

1. Jerusalem--Symbolic representation.

2. Visual communication.

3. Communication in architecture.

4. Church architecture--Jerusalem.

5. Church architecture--Europe.

6. Sacred space--Jerusalem.

7. Sacred space--Europe.

8. Christian art and symbolism--Jerusalem.

9. Christian art and symbolism--Europe.

10. Palestine--Maps--Early works to 1800.

I. Series

II. Kuhnel, Bianca editor.

III. Noga-Banai, Galit, 1966- editor.

IV. Vorholt, Hanna editor.

V. Visual Constructs of Jerusalem (Conference) (2010 : Jerusalem), associated with work.

704.9'499569442-dc23

ISBN-13: 9782503551043

This volume has been produced under the auspices of the research project SPECTRUM Visual Translations of Jerusalem, based at the Hebrew University of Jerusalem. Research leading to these results has received funding from the European Research Council under the European Union's Seventh Framework Programme (FP7/2007-2013) / ERC grant agreement no. 249466.

\section{(c) 2014, Brepols Publishers n.v., Turnhout, Belgium}

All rights reserved. No part of this publication may be reproduced, stored in a retrieval system, or transmitted, in any form or by any means, electronic, mechanical, photocopying, recording, or otherwise, without the prior permission of the publisher.

$\mathrm{D} / 2014 / 0095 / 190$

ISBN: 978-2-503-55104-3

e-ISBN: 978-2-503-55121-0

Printed in the EU on acid-free paper 


\section{CONTENTS}

List of Illustrations . . . . . . . . . . . .

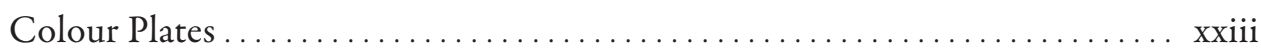

Acknowledgements ................................................

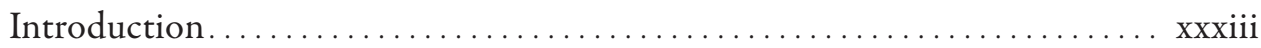

\section{Loca sancta: Formation and Accumulation of Traditions}

'Remembering Sion': Early Medieval Latin Recollections of the Basilica on Mount Sion and the Interplay of Relics, Tradition, and Images

THOMAS O'LOUGHLIN ..................................

Mary in Jerusalem: An Imaginary Map

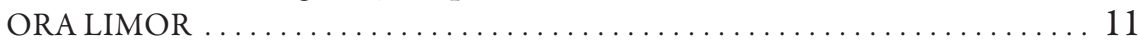

Lavit et venit videns: The Healing of the Blind Man at the Pool of Siloam

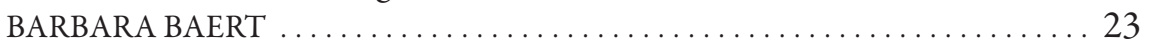

Patronage Contested: Archaeology and the Early Modern Struggle

for Possession at the Church of the Nativity, Bethlehem

JORDAN PICKETT ..................................... 35

From Biblical to Non-Biblical Holy Places:

The Shrine of Subiaco as a Construct of Jerusalem

ALESSANDRO SCAFI .................................. 45

\section{Monumental Translations}

How Mtskheta Turned into the Georgians' New Jerusalem

TAMILA MGALOBLISHVILI ................................. 59

Locative Memory and the Pilgrim's Experience of Jerusalem

in the Late Middle Ages

MICHELE BACCI..................................... 67

New Research on the Holy Sepulchre at the 'Jerusalem' of San Vivaldo, Italy RICCARDO PACCIANI ................................ 77

Pilgrimage Experience: Bridging Size and Medium

TSAFRA SIEW

The Baptistery of Pisa and the Rotunda of the Holy Sepulchre:

A Reconsideration

NETA BODNER 


\section{Strategies of Translation}

From Sanctified Topos to Iconic and Symbolic Model:

Two Early Representations of the Holy Sepulchre in Croatia MARINA VICELJA-MATIJAŠIĆ . .

Defending Jerusalem: Visualizations of a Christian Identity in Medieval Scandinavia KRISTIN B. AAVITSLAND

Jerusalem in Medieval Georgian Art GEORGE GAGOSHIDZE.

A (Hi)story of Jerusalem: Memories and Images in the Austro-Hungarian Empire

LILY ARAD.

The Running Girl in Mea Shearim: Gender, Nostalgia, and the Uncanny in Leora Laor's Photography (2002-04)

MILLY HEYD

\section{Evocations of the Temple}

Reconstructing Jerusalem in the Jewish Liturgical Realm:

The Worms Synagogue and its Legacy

SARIT SHALEV-EYNI

Beyond the Veil: Roman Constructs of the

New Temple in the Twelfth Century

EIVOR ANDERSEN OFTESTAD

Heavenly Jerusalem in Baroque Architectural Theory

VICTOR PLAHTE TSCHUDI.

King Solomon's Temple and Throne as Models in Islamic Visual Culture

RACHEL MILSTEIN

\section{Relics, Reliquaries, and Ritual}

Holy Places and Their Relics

BRUNO REUDENBACH

The True Cross of Jerusalem in the Latin West:

Mediterranean Connections and Institutional Agency

NIKOLAS JASPERT

'Living Stones' of Jerusalem: The Triumphal

Arch Mosaic of Santa Prassede in Rome

ERIK THUNØ

Strategies of Constructing Jerusalem in Medieval Serbia

JELENA ERDELJAN.

The Holy Fire and Visual Constructs of Jerusalem, East and West

ALEXEI LIDOV... 
Maps of Jerusalem

From Eusebius to the Crusader Maps: The Origin of the Holy Land Maps MILKA LEVY-RUBIN

Heavenly and Earthly Jerusalem:

The View From Twelfth-Century Flanders JAY RUBENSTEIN

Quaresmius's Novae Ierosolymae et Locorum Circumiacentium Accurata Imago (1639): An Image of the Holy City and its Message REHAV RUBIN

An American Missionary's Maps of Jerusalem: Past, Present, and Future EVELYN EDSON.

\section{Maps of the Holy Land}

Experiencing the Holy Land and Crusade in Matthew Paris's Maps of Palestine LAURA J. WHATLEY.

'As If You Were There': The Cultural Impact of Two Pilgrims' Maps of the Holy Land PNINA ARAD

Mapping the History of Salvation for the 'Mind's Eyes': Context and Function of the Map of the Holy Land in the Rudimentum Novitiorum of 1475

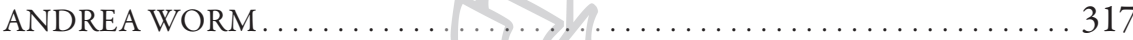

Ottheinrich and Sandtner: Sixteenth-Century Pilgrimage Maps and an Imaginary Model of Jerusalem HAIM GOREN

\section{Mappae Mundi}

The City of the Great King: Jerusalem in Hugh of Saint Victor's Mystic Ark CONRAD RUDOLPH.

The Jerusalem Effect: Rethinking the Centre in Medieval World Maps MARCIA KUPFER

\section{Manuscripts and Panel Painting}

Ducitur et reducitur: Passion Devotion and Mental Motion in an Illuminated Meditationes Vitae Christi Manuscript (Oxford, Corpus Christi College, MS 410)

Virtual Pilgrimage through the Jerusalem Cityscape 


\section{Pilgrimage Literature and Travelogues}

Representations and Descriptions of Jerusalem in the

Printed Travelogues of the Early Modern Period

MILAN PELC

The Jerusalem of the Mind's Eye: Imagined Pilgrimage

in the Late Fifteenth Century

KATHRYNE BEEBE

Memory and Representations of Jerusalem in

Medieval and Early Modern Pilgrimage Reports

MARIA E. DORNINGER

Richard Pococke, or the Invention of Jerusalem for Tourists

OLGA MEDVEDKOVA.

\section{Byzantine Approaches}

Visualizing the Tomb of Christ: Images, Settings, and Ways of Seeing ROBERT OUSTERHOUT

'Remembering Zion' and Simulacra: Jerusalem in the Byzantine Psalter MATI MEYER

Souvenirs of the Holy Land: The Production of Proskynetaria in Jerusalem MAT IMMERZEEL .

Proskynetaria as Devotional Objects and Preservers of Ethnic Identity MÁRTA NAGY

Index 


\section{LAVIT ET VENIT VIDENS: THE HEALING OF THE BLIND MAN AT THE POOL OF SILOAM}

So I will shut my eyes tight and write quickly: I wish that two total strangers could overcome strangeness itself

David Grossman, Be My Knife, trans. by Vered Almog and Maya Gurantz

(New York: Picador, 2001), p. 8
$\mathrm{T}$ The episode of the blind man at Siloam has not received much attention in research on medieval iconography in general and Jerusalem visual studies in particular. In this article I will deal with the theme as a model for the interactions among narrative, visual media, and sacred topography. How does Scripture correspond to the imagery that evokes the event and place? What position does the pool of Siloam hold in the cultural and symbolic patterns of holy places in Jerusalem throughout the Middle Ages? How can we define the relationship between the loca sancta of the centre and the periphery (the pool outside the city wall)? And how will these questions contribute to a better understanding of the iconization of a 'construct' we call Jerusalem?

\section{Topos and Memoria}

As he walked along, he saw a man blind from birth. His disciples asked him, 'Rabbi, who sinned, this man or his parents, that he was born blind?' Jesus answered, 'Neither this man nor his parents sinned; he was born blind so that God's works might be revealed in him. We must work the works of him who sent me while it is day; night is coming when no one can work. As long as I am in the world, I am the light of the world.' When he had said this, he spat on the ground and made mud with the saliva and spread the mud on the man's eyes, saying to him, 'Go, wash in the pool of Siloam' (which means Sent). Then he went and washed and came back able to see. The neighbors and those who had seen him before as a beggar began to ask, 'Is this not the man who used to sit and beg?' Some were saying, 'It is he.' Others were saying, 'No, but it is someone like him.' He kept saying, 'I am the man.' But they

\author{
Barbara Baert \\ Catholic University of Leuven
}

kept asking him, 'Then how were your eyes opened?' He answered, 'The man called Jesus made mud, spread it on my eyes, and said to me, "Go to Siloam and wash." Then I went and washed and received my sight."

In this episode in John 9.1-14, the healing of the man who was born blind is placed in the context of a real setting: the pool (natatorium) of Siloam in the valley southwest of the city. The Gihon spring on Mount Ophel, now known as the spring of the Virgin, flows from a rock in an eight-metre-deep pool that is channelled through galleries to the pool of Siloam. ${ }^{2}$ The pool of Siloam is mentioned already in Isaiah 8. 6: 'Because this people have refused the waters of Shiloah that flow gently'

For the Wirkungsgeschichte of the pool of Siloam site, we must turn to pilgrims' reports and archaeological remains. ${ }^{3}$ Under the emperor Hadrian (r. 117-38), it

1 Unless otherwise noted, all passages from the Bible are taken from the New Revised Standard Version.

2 Louis-Hugues Vincent, Jérusalem: recherches de topographie, d'archéologie et d'histoire, I, Jérusalem antique (Paris: Gabalda, 1912), pp. 264-79, with an image of the so-called Gihon chamber today, fig. 73; Ahron Horovitz, City of David: The Story of Ancient Jerusalem, ed. by Eyal Meiron (Jerusalem: Lambda, 2009).

3 Louis-Hugues Vincent and F. M. Abel, Jérusalem: recherches de topographie, d'archéologie et d'histoire, II, Jérusalem nouvelle (Paris: Gabalda, 1926), pp. 860-62; Henri Leclercq, 'Jérusalem', in Dictionnaire d'archéologie chrétienne et de liturgie, ed. by Fernand Cabrol and Henri Leclerq, 15 vols (Paris: Letouzey et Ané, 1907-53), vir.2 (1927), cols 2304-74 (cols 2329-30) and fig. 6182; Eugene Hoade, Guide to the Holy Land (Jerusalem: Franciscan Press, 1962), pp. 243-47. 
may have been dedicated to Fortuna balnearis. ${ }^{4}$ During the time of Aelia Capitolina (as Jerusalem was renamed in 135), the Siloam site already encompassed a tetranymphon. The Pilgrim of Bordeaux reports in 333 that there was a pool on Mount Sion called Silua (sic), which had four gates. From the reign of Valentinian (364-75), the Georgian Typikon of Jerusalem mentions an oratory that was probably meant to replace the Roman tetranymphon. Around 400, Prudentius sings the praises of the site: 'Remedy for diseases, the water that an air current slowly discharges: the reason for its flow is unknown; they call it Siloam, where the Saviour smeared the blind man's eyes with his saliva and told him to wash them in the spring. ${ }^{5}$ On the basis of the biography of Peter the Iberian, we know that from at least 451 there was a sanctuary in use there. He describes a Monophysite ceremony conducted by Archbishop Theodosius in the 'church called Siloe' or the church of 'Our Saviour, the Light', which recalls the words of Christ-'I am the light of the world' (John 9.5). Peter supposedly visited the church again in his pilgrimage of 482. An anonymous account describes the church in the sixth century as ecclesia volubilis. The author writes that Empress Eudokia was engaged in the improvement of the site, extending the walls so that the church would become part of the inner city. ${ }^{6}$ From the descriptions of Sophronius (603), we can deduce that the canal passed under the apse of the domed church and flowed directly into a pool that was divided in two by a pulpit. In this way women and men could bathe separately. To the south of this construction was a second pool, which was separated from the double pool by a columned atrium. ${ }^{7}$

4 For what follows: Vincent and Abel, Jérusalem: recherches de topographie, II, 880.

5 Prudentius, Le Livre des couronnes (Peristephanon liber) Dittochaeon: épilogue, trans. by M. Lavarenne, Collection des universités de France, 4 (Paris: Belles Lettres, 1963), p. 212: 'Morborum medicina latex, quem spiritus horis | eructat variis fusum ratione latenti, | Siloam vocitant, sputis ubi conlita caeci | lumina salvator iussit de fonte lavari.'

6 Anonymous, in Itinera Hierosolymitana saeculi IIII-VIII, ed. by Paul Geyer, Corpus Scriptorum Ecclesiasticorum Latinorum, 39 (Vienna: Tempsky, 1898), pp. 7-8.

7 Eusebius (in 332) mentions that the underground water is coloured red: Onomastikon 58, 21, in Eusebiii Pamphilii Episcopi Caesariensis Onomasticon: urbium et locorum Sacrae Scripturae, ed. by F. Larsow and G. Parthey (Berlin: Nicolai, 1862). The red water refers to the mineral properties of the rock bottom. In it Eusebius recognized the blood of the priest Zacharias, the father of John the Baptist, who was killed in the Temple and permanently coloured the nearby water. For the earliest witnesses see Frederick Jones Bliss, Excavations at Jerusalem 1894-1897 (London: Committee of the

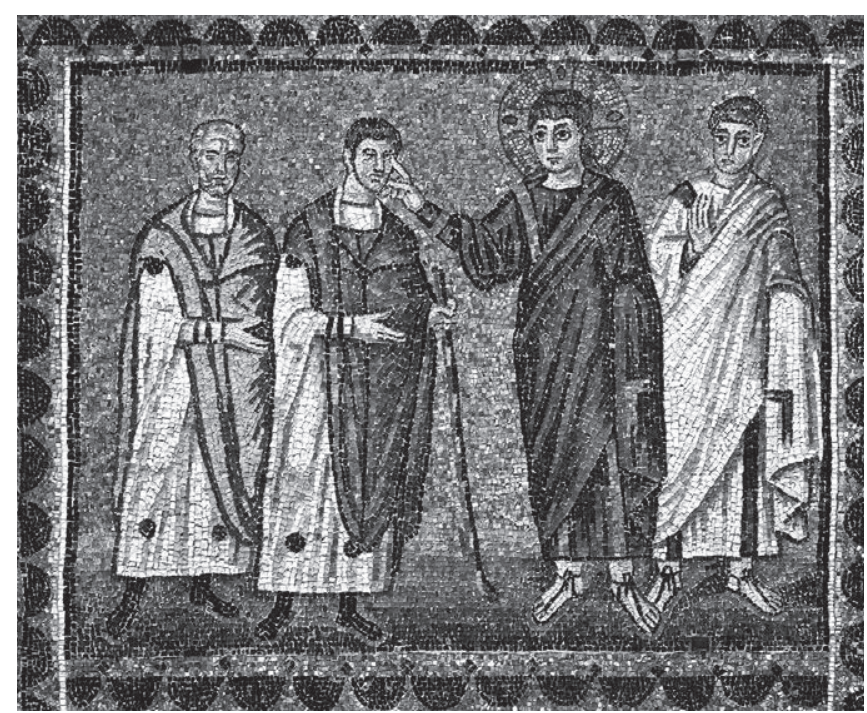

Figure 3.1. Ravenna, Sant'Apollinare Nuovo, Healing of the Blind Man, mosaic, 520-26 (photo (C) Ravenna, Sant’Apollinare Nuovo).

During the Crusades there was a heightened interest in Jerusalem's water system. The crusaders realized that understanding the underground system of canals was of strategic importance for Jerusalem. In her impressive article on the city's water supply, Evelyn Edson deals with this new point of interest by taking into account the crusaders' maps of the canals, aqueducts, water reservoirs, and cisterns. ${ }^{8}$ The map of Jerusalem in a manuscript of 1320 containing the Liber secretorum fidelium crucis super Terrae Sanctae recuperatione et conservatione (The Book of Secrets of the Faithful of the Cross on How to Recapture and Retain the Holy Land), by the Venetian merchant Marino Sanudo, is a good example of this new interest. ${ }^{9}$ Sanudo apparently never visited the

Palestine Exploration Fund, 1898), pp. 154-55, 178-210; Early Travels in Palestine: Comprising the Narratives of Arculf, Willibald, Bernard, Saewulf, Sigurd, Benjamin of Tudela, Sir John Maundeville, De la Brocquiere, and Maundrell, ed. with notes by Thomas Wright (London: Bohn, 1848; repr. New York: AMS, 1969), p. 42; Peregrinationes tres: Saewulf, John of Würzburg, Theodericus, ed. by R. B. C. Huygens, Corpus Christianorum, Continuatio Mediaevalis, 139 (Turnhout: Brepols, 1994), p. 69.

8 Evelyn Edson, 'Jerusalem under Siege: Marino Sanudo's Map of the Water Supply, 1320', in Imagining Jerusalem in the Medieval West, ed. by Lucy Donkin and Hanna Vorholt, Proceedings of the British Academy, 175 (Oxford: Oxford University Press, 2012), pp. 201-07.

9 Part XIV of Book III of Mario Sanuto's Secrets for True Crusaders to Help Them Recover the Holy Land, trans. by Aubrey Stewart, Palestine Pilgrims' Text Society [hereafter PPTS], 12.2 (London: Committee of the Palestine Exploration Fund, 1896). This edition contains only the desciption of Jerusalem. It is illustrated with redrawn maps of the Holy Land, the eastern Mediterranean, 


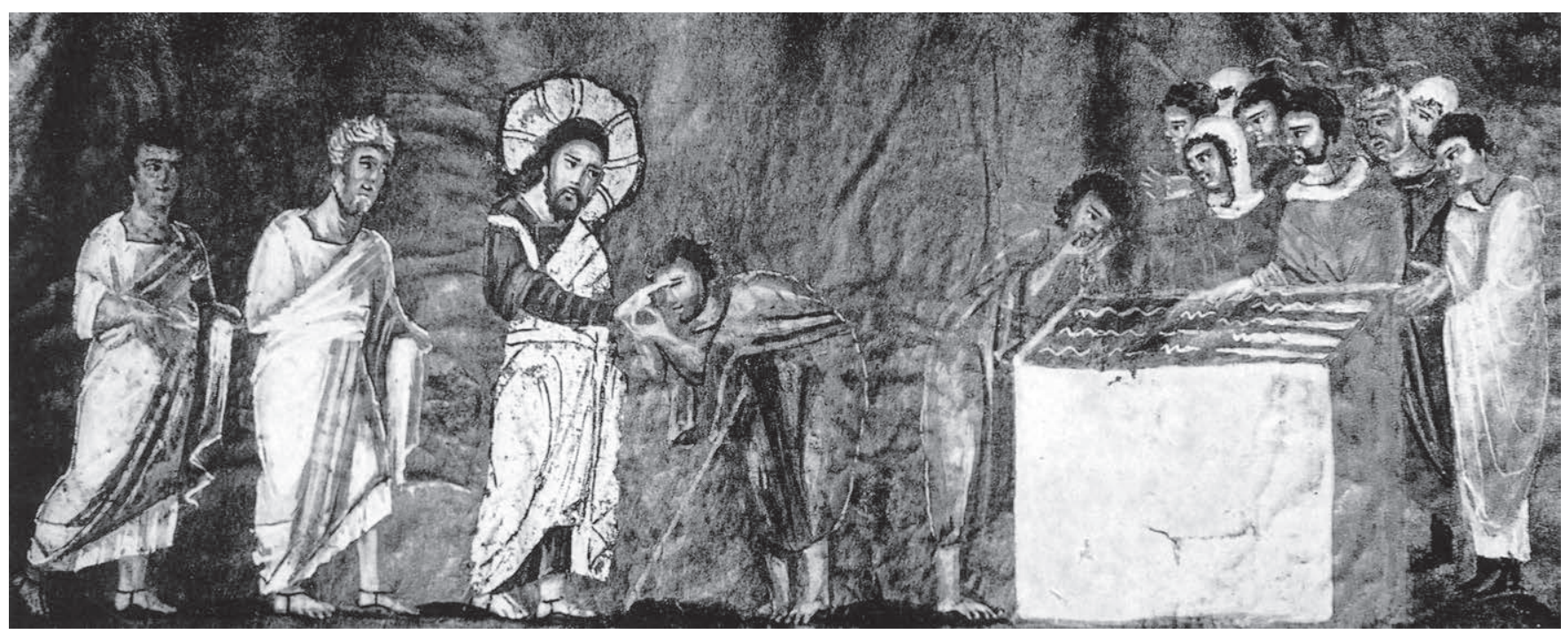

Figure 3.2. Rossano Gospels, Rossano, Museo dell'Arcivescovado, fol. $7^{\mathrm{r}}$, Healing at the Pool of Siloam, third quarter of sixth century (photo: Arthur Erich Georg Haseloff, Codex Purpureus Rossanensis. Die Miniaturen der griechischen Evangelien-Handschrift in Rossano [Berlin: Giesecke \& Devrient, 1898], pl. IX).

Holy Land; he based his account on the detailed descriptions found in the Description of the Holy Land written by Burchard of Mount Sion. ${ }^{10}$ Burchard, a Dominican friar from Germany, travelled to the East in the late thirteenth century and spent ten years at the monastery of Mount Sion in Jerusalem. Burchard paid special attention to the water resources of the city and Sanudo follows him faithfully. According to Burchard, the spring of Siloam supplied water to the Lower Pool and the Natatorium, or bathing pool of Siloam, while these pools also received water from the lower spring of Gihon. $\mathrm{He}$ explained that Hezekiah's tunnel had diverted the waters of the spring of Gihon around to the west and across the city into the Inner Pool by the Church of St Anne, the piscina Probatica. This water also supplied the Upper Pool to the west of the city.

\section{Topos and Symbol}

The Gospel of John features two actions that bring about the blind man's miraculous healing: the anointment

and Jerusalem. The Latin text from the printed Hannover edition of 1611, edited by Jacques Bongars, is available in Liber secretorum fidelium Crucis super Terrae Sanctae recuperatione et conservatione (Toronto: University of Toronto Press, 1972), with a foreword by Joshua Prawer. Prawer includes a set of colour maps from London, British Library, MS Add. 27376.

10 Burchard of Mount Sion, A.D. 1280, trans. by Aubrey Stewart, with geographical notes by C. R. Conder, PPTS 12.1 (London: Committee of the Palestine Exploration Fund, 1896; repr. New York: AMS, 1971). of the eyes with mud and the washing of the eyes with water from the pool. Between these two actions Christ's instruction takes place: he sends the man to the pool. In early Christian and early Byzantine iconography, the scene is compressed to a dialogue between Christ and the blind man in which hand gestures indicate that the healing of the eyes is being depicted. ${ }^{11}$ This is the case on sarcophagi, ${ }^{12}$ on a sixth-century ivory kept in the Vatican, ${ }^{13}$ on one of the panels of the throne of Maximianus in Ravenna (545), ${ }^{14}$ and in a mosaic at Sant'Apollinare Nuovo in Ravenna (520-26) (Fig. 3.1).

The blind man is represented as a youth; only on the Maximianus throne and in the Rossano Gospels codex is he bearded (Fig. 3.2). His staff accentuates his handicap, and the more specific handicap of being blind can

11 In 2007 I catalogued the iconography; see Barbara Baert, 'The Healing of the Blind Man at Siloam, Jerusalem: A Contribution to the Relationship between Holy Places and the Visual Arts in the Middle Ages', Part I, Arte Cristiana, 95, no. 838 (2007), 49-60; Part II, Arte Cristiana, 95, no. 839 (2007), 121-30, with older bibliography.

12 See Giuseppe Wilpert, I sarcofagi cristiani antichi, 3 vols (Rome: Pontificio istituto di archeologia cristiana, 1929-36), I (1929), figs XI-1, XXIX-3, XL, LXXXVI-3, LXXXXI, LXXXXII, LXXXXVI, CXV-1, 2, 3, CXII-2, 3, CXIII-1, 3, CXIV-1, CXV-11, CXVI-2, CXXIII, CXXVI-1, 2, CXXVII-1, 2, CXXVIII-1, 2, cXXXV-2, cXXXVII-6, CXXXIX-1, CXXXX-7, CXXXXV-7, CLII-5, CLVI, CLVII-2, CLVIII-3.

13 Wolfgang Fritz Volbach, Elfenbeinarbeiten der Spätantike und des frühen Mittelalters (Mainz: Zabern, 1952), no. 138, plate 46.

14 Archiepiscopal Museum; Carlo Cecchelli, La cattedra di Massimiano ed altri avori romani-orientali (Rome: Libreria dello Stato, 1936-44), pp. 188-89. 


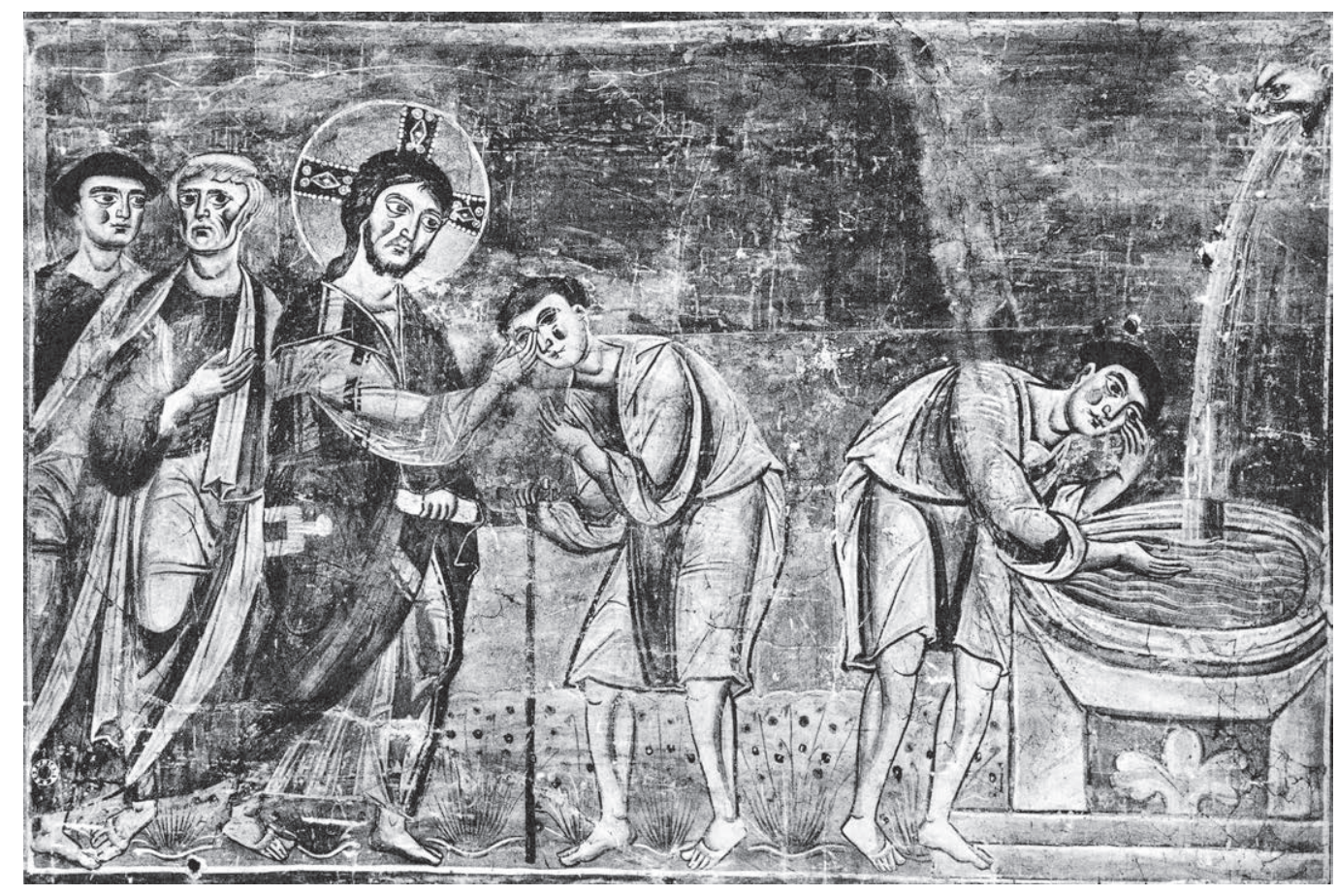

Figure 3.3. Sant'Angelo in Formis, Healing at the Pool of Siloam, fresco, c. 1080 (photo: Glenn Gunhouse, The Fresco Decoration of Sant'Angelo in Formis [Ann Arbor, MI: UMI Dissertation Information Service, 1994]). be deduced from the fact that his eyes are either closed or tightly shut. Closed eyes contrast with open eyes in the scene at the pool. This contrast is particularly clear in a mural painting at Sant'Angelo in Formis (Fig. 3.3). What is also remarkable is the fact that the motif of the mud and the saliva is rarely represented as such. On the cover of the Codex Aureus of St Emmeram (Fig. 3.4) 15 $^{15}$ and in the fresco at Sant'Angelo in Formis, even the act of touching is ambiguous: it is simultaneously-and perhaps even primarily - a blessing. In the Codex Egberti, Christ's intervention is further dematerialized (Fig. 3.5). The act of touching is filtered out, and the miraculous power of Christ as Logos is allowed to operate exclusively. ${ }^{16}$ Note also the epigraphy: aquaductus Siloe. Only in the miniature in the prayer book of Hildegard of Bingen does Christ indeed rub a small amount of some substance in his palm with his ring finger. ${ }^{17} \mathrm{With}$ his eyes shut, the

15 Munich, Bayerische Staatsbibliothek, MS Clm 14000, c. 870.

16 For a similar argument see Jane Hawkes, 'Sacraments in Stone: The Mysteries of Christ in Anglo-Saxon Sculpture', in The Cross Goes North: Processes of Conversion in Northern Europe, AD 300-1300, ed. by Martin Carver (Woodbridge: York Medieval Press; Rochester, NY: Boydell \& Brewer, 2003), pp. 351-70. The author also deals with the healing of the blind man on the cross at Ruthwell. The scene belongs to the early Christian phase.

17 From Trier, before 1179; now Munich, Bayerische Staatsbibliothek, MS lat. 935, fol. 42vi Hildegard-Gebetbuch. FaksimileAusgabe des Codex Latinus monacensis 935 der Bayerischen Staatsbibliothek (Wiesbaden: Reichert, 1982-87), fol. 42vi Elisabeth blind man waits for what will happen next. The adjoining text says: 'Hier macht unser Herr einen geborenen Blinden sehend, der von seiner Geburt an blind war' (Here our Lord makes one born blind to see, who was blind from birth). The pool of Siloam is not represented.

In the works cited, there is little uniformity in the representation of the pool of Siloam. The pool varies in shape from square to cruciform; sometimes it is a round well. The water in the pool is sometimes still, sometimes flowing from the mouth of a gargoyle. In the mural at Sant'Angelo in Formis, the pool of Siloam is a stone well that suggests a square base with a round opening; the front is decorated with a three-lobed plant motif (Fig. 3.3). Plant motifs are often associated with water as a symbol of fertility and regenerative forces. Consequently, schematized plants are also associated with the water of life. ${ }^{18}$ The motif of a three-lobed plant

Klemm, Die romanischen Handschriften der Bayerischen Staatsbibliothek, II, Die Bistümer Freising und Augsburg (Wiesbaden: Reichert, 1988), p. 207.

18 The three-lobed plant as a sign of the tree of life and the water of life is discussed in August Wünsche, Die Sagen vom Lebensbaum und Lebenswasser: altorientalische Mythen (Leipzig: Pfeifer, 1905); Zofja Ameisenowa, 'The Tree of Life in Jewish Iconography', in Journal of the Warburg Institute, 2.4 (1939), 326-45. Romuald Bauerreiss, Arbor Vitae: der 'Lebensbaum' und seine Verwendung in Liturgie, Kunst und Brauchtum des Abendlandes (Munich: Neuer Filser, 1938), gives examples of the joining of source and vegetation symbolism in the context of regenerative liturgy, like baptism. 


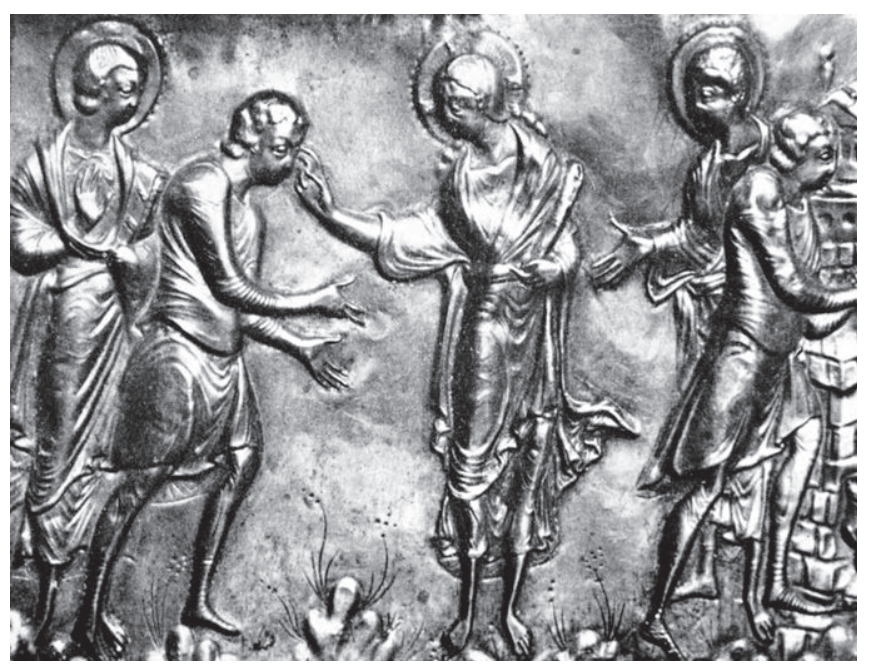

Figure 3.4. Codex Aureus of St Emmeram, Munich, Staatsbibliothek, MS Clm 14000, detail of book cover, Healing at the Pool of Siloam, c. 870 (photo $@$ Munich, Bayerische Staatsbibliothek).

is a typical, occasionally abstract decoration found on baptismal fonts, such as an early medieval example in Gerpinnes, France, which features a square base with a round basin supported by columns. ${ }^{19}$ Early medieval representations of basins, the fountain of life, and baptismal fonts seem to be formally interchangeable.

The gargoyle in the shape of a lion's head at Sant'Angelo in Formis is a typical decorative element. Additionally, the roaring lion is a symbol of Resurrection. ${ }^{20}$ It also calls to mind the fourth-century Hymnus antelucanus de Christo of Hilarius of Poitiers: Te leonem legimus. ${ }^{21}$ In fact, the popular belief that the lion sleeps with his eyes open evokes a connection with the open-eyed-that is, cured-blind man. The lion is a popular motif on baptismal fonts, ranging from decorations on the base and frieze to direct allusions to the lion of Judah. ${ }^{22}$

The gargoyle in the shape of a peacock in the Codex Egberti also is presumably more than a graceful decorative motif (Fig. 3.5). The peacock was venerated in the

19 The early medieval basin, fountain of life, and font are formally interchangeable; examples can be found in W. A. von Reybekiel, Der 'fons vitae' in der christlichen Kunst (Bremen: s.n., 1934).

20 Xosé Ramón Mariño Ferro, Symboles animaux: un dictionnaire des représentations et croyances en Occident (Paris: Desclée de Brouwer, 1996), p. 202.

21 As noted by Singelenberg, 'The Iconography of the Etschmiadzin Diptych', p. 110.

22 See examples in Folke Nordström, Mediaeval Baptismal Fonts: An Iconographical Study (Umeá: Almqvist \& Wiksell, 1984), p. 55 and figs $35,49,53$.

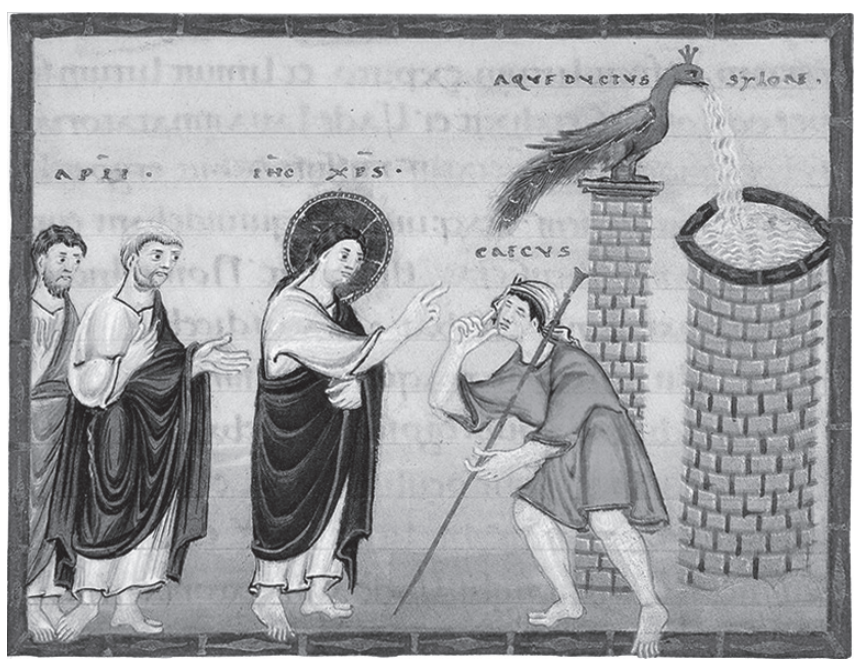

Figure 3.5. Codex Egberti, Trier, Stadtbibliothek, MS 24, fol. $50^{\mathrm{r}}$, Healing at the Pool of Siloam, 977-93 (photo @ Trier, Stadtbibliothek).

Middle Ages, with the impressive eyes on its feathers associated with the all-seeing eye of God. ${ }^{23}$ In the context of the man who was born blind, the choice of a peacock is subtly connected to sight and to insight in the Logos. An eighth-century ambo in the Abbey of San Salvatore and Santa Giulia in Brescia features banisters representing a peacock. This Lombard stone relief points to the power of the word in the Gospel and the truth that it provides. ${ }^{24}$ Moreover, it was believed that the meat of the peacock was incorruptible; hence, the bird was also known as a symbol of immortality. The water pouring out of its beak into the well is thus water of eternal life. For that reason, the peacock is often represented in the context of the fountain of life, as in the miniature in the lectionary of Godescalc, made to commemorate the christening of Charlemagne's son (781-83). ${ }^{25}$ By using a peacock as a gargoyle for the pool of Siloam, the miniaturist connects the story of the miracle to eternal life through the Word of God. ${ }^{26}$

23 Nordström, Medieval Baptismal Fonts, pp. 72-73.

24 Now Brescia, Museo della Città; F. Morandini, 'Fragmente eines Ambo', in Krone und Schleier: Kunst aus mittelalterliche Frauenklöstern, ed. by Jutta Frings and Jan Gerchow (Munich: Hirmer, 2005), no. 38, pp. 199-200.

25 Paris, Bibliothèque Nationale de France, MS lat. 1203, fol. $3^{v}$. Other examples of fountains of life with peacocks can be found in Paul A. Underwood, 'The Fountain of Life in Manuscripts of the Gospels', Dumbarton Oaks Papers, 5 (1950), p. 88, figs 25-26. Bruno Reudenbach, Das Godescalc-Evangelistar: ein Buch für die Reformpolitik Karls des Großen (Frankfurt: Fischer, 1998).

26 For that reason, the peacock is also often found in a funerary 


\section{Water as Medium}

In a Byzantine copy (880-86) of the homilies of Gregory of Nazianzus, an angel touches the water of the Siloam spring with his staff (Fig. 3.6). ${ }^{27}$ This motif is not mentioned in John 9 but in John 5. 1-8, in connection with the healing of the lame man at the pool of Bethesda or piscina Probatica, mentioned above. In the context of the healing of the lame man, the angel stirs the water of the piscina Probatica daily, thereby releasing a surge of healing substances. The first to descend into the pool will be healed. The lame man also believes in the healing power of the minerals, but his handicap prevents him from entering the water at the right moment. The story continues with Christ telling him, 'Stand up, take your mat and walk.' At once the man is healed, which is followed by a dispute concerning Christ's acting on the sabbath. In the piscina Probatica episode, the magic of the spring is thus diverted more radically toward the word of God than in the episode at Siloam; indeed, the lame man no longer needs the water to be healed.

The tides described in accounts of the piscina Probatica are part of the physiological reality of Jerusalem. ${ }^{28}$ The water of the piscina is transported by means of an ingenious underground canal system that was dependent on the welling tides of the Gihon; even Sanudo knew this. ${ }^{29}$ Perhaps the miniaturist of the homilies was also familiar with the phenomenon and therefore had the angel of John 9 appear by Siloam, although it remains an iconographic rarity. Whatever the case, the water of Siloam does not play an accidental role in John 9; it cleanses, heals, and produces the truth. When the blind man is enlightened by water, a miracle takes place that also occurs in the sacrament of baptism. ${ }^{30} \mathrm{In}$

context, as on Lombard sarcophagi: Nordström, Medieval Baptismal Fonts, p. 73; Marion Lawrence, The Sarcophagi of Ravenna, Monographs on Archaeology and Fine Arts, 2 (New York: College Art Association, 1945), p. 44.

27 Paris, Bibliothèque nationale de France, MS grec. 510, fol. $316^{\mathrm{r}}$

28 Vincent, Jérusalem: recherches de topographie, I, 260-88; see also Konstantin Hartte, Zum semitischen Wasserkultus (vor Ausbreitung des Christentums) (Halle: Schlesingerische Buchdruckerei, 1912), pp. 18-20; Philippe Reymond, L'eau, sa vie, et sa signification dans l'Ancien Testament (Leiden: Brill, 1958).

29 In 1873 the site was excavated under the guidance of archaeologist Charles Mauss; Joachim Jeremias, Die Wiederentdeckung von Bethesda, Johannes 5.2 (Göttingen: Vandenhoeck \& Ruprecht, 1949), pp. 9-11.

30 See Peter Cramer, Baptism and Change in the Early Middle

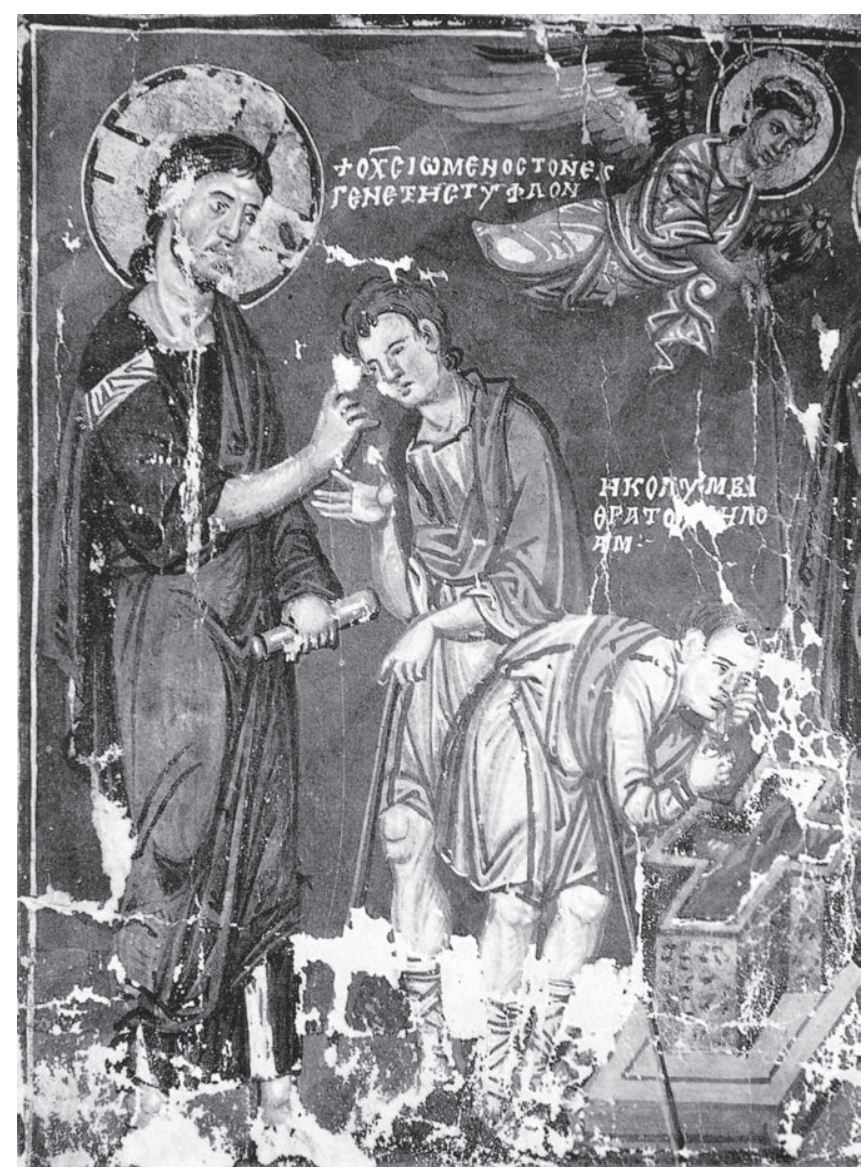

Figure 3.6. Homilies of Gregory of Nazianzus, Paris, Bibliothèque Nationale de France, MS grec. 510, fol. 316r, Healing at the Pool of Siloam, 880-86 (photo (c) Paris, Bibliothèque Nationale de France).

the Greek-speaking world, the word for a place to bathe or swim-kolumbithra-could also refer to a baptistery. ${ }^{31}$ The blind man thus becomes a baptized missionary who bears eternal life within him as a model for the community.

In his introduction to the sacraments, Ambrose (339-97) also discusses the passage in which the blind man is healed in the context of baptism. ${ }^{32}$ He says that

Ages, c. 200-c. 1150 (Cambridge: Cambridge University Press, 1993). The association between the healing of the man born blind and baptism is supported by the fact that the motif on the sarcophagi is connected to Moses who strikes water out of the rock, a well-known prefiguration of baptism and a symbol of regeneration in a Semitic context: Germain Bienaimé, Mö̈se et le don de l'eau dans la tradition juive ancienne: Targum et Midrash (Rome: Biblical Institute, 1984).

31 Singelenberg, 'The Iconography of the Etschmiadzin Diptych', p. 107.

32 St. Ambrose, "On the Mysteries" and the Treatise On the Sacraments, by an Unknown Author, trans. by T. Thompson, ed. by J. H. Strawley (London: Society for Promoting Christian Knowledge, 
John presents in this passage a prefiguration of the mystery and the effects of baptism. The evangelist distinguishes himself from the other evangelists by using the motif of the mud. Ambrose interprets this motif in the context of the washing away of sins: Christ smeared the blind man's eyes with mud in order to show him his sins. The mud, according to Ambrose, represents humility and a sense of guilt for individual and inherited sins. 'Being sent' to Siloam means to 'confess' this guilt. If the blind man bathes in the pool and sees again, then it is precisely because he sees with his heart. Only in this awareness can a true rebirth by baptism occur. Ambrose then connects the pool of Siloam in the context of baptism to the metaphor of the so-called 'spring' of the cross: the spring in which Christ redeemed humanity. ${ }^{33}$ These reflections are devoted to the fact that the eyes have been opened by the Passion of Christ. The one who has been baptized has, to paraphrase Ambrose, reached the altar of the truth. This is also reflected in the rites of the church.

In the Sacramentarium Leonianum (seventh century), prayers are included for the blessing of the font (benedictio fontis) on Holy Saturday. At the beginning, the Holy Spirit is invoked and asked to wash away all that is dirty, all 'stains of sin': 'Hic omnium peccatorum maculae deleantur'. The baptismal font becomes the fountain of life, the regenerative water and purifying stream that comes from the wound in Christ's side (sit fons vivus, aqua regenerans, unda purificans qui te una cum sanguine de latere suo produxit). The one who is baptized is compared with one reborn of an immaculate womb: 'ut, sanctificatione concepta, ab immaculato divini fontis utero in novam renata creaturam progenies caelestis emergat. ${ }^{34}$

In the miniature of the homilies of Gregory of Nazianzus, the spring has the shape of a Greek cross (Fig. 3.6). ${ }^{35}$ There are countless examples of baptisteries with a Greek-cross plan, ${ }^{36}$ including the early Christian

1919), Book 3, Chap. 2, pp. 8-15; v. 12: 'Thou hast to see the things which thou didst not see before, that is, the mystery which thou read in the Gospel; and thou wast not yet able to see with the eyes of the heart.'

33 Underwood, 'The Fountain of Life', pp. 59-70.

34 For all translations see Underwood, 'The Fountain of Life', pp. 59-60: 'May, after we have received the Holiness of the immaculate womb of the holy well, emanate a holy generation from a reborn new Creation'.

35 See the above-mentioned copy, MS grec. 510, fol. $316^{\mathrm{r}}$.

36 More in Franz-Joseph Dölger, 'Zur Symbolik des altchristlichen Taufhauses', in Antike und Christentum, 2nd ser., 4 (1934), 153-87. example in Pola. ${ }^{37}$ The first Palestinian baptismal fonts were much more like baths in which baptism by immersio took place, and these were often cruciform as well. The Greek cross combines the symbolism of the quaternity - the four rivers of Paradise, the four evangelistswith the Passion of Christ. In the Homilies manuscript, the pool of Siloam refers to the sacrifice of Christ, in which the sins of humanity are washed away. The miniaturist, in other words, characterizes the pool as a source of mercy. The concept of the Fons pietatis was already mentioned by Gregory the Great (540-604). He compares Christ with a source of mercy in which we sinners must immerse ourselves in order to wash away our sins. ${ }^{38}$ In the seventh-century Gelasian Sacramentary, Christ is venerated as the Fons pietatis that must save us from our sins. ${ }^{39}$ The text says that the blind man is a representative of humanity, which must be purified in a spring, a source-Christ himself-from whom water and blood flowed. John Chrysostom (354-407) says that the water (from the wound in Christ's side) is the image of salvation that springs from the body of Christ; his body is a source of eternal life. ${ }^{40}$ An inscription that was inscribed in the baptistery of the Lateran around 440, during the papacy of Leo the Great, reads 'Fons hic est vitae qui totum diluit orbem / Sumens de Christi vulnere principium. ${ }^{41}$ In this way, the cruciform font, just as in the miniature of the homilies of Gregory of Nazianzus, is connected with the Holy Sepulchre. This association was made early on: Augustine (354-430) says, 'Propter sepulturam: Consepulti enim sumus Christo per baptismum in mortem', 'one must enter into the death of

37 Underwood, 'The Fountain of Life', fig. 70; see also Walter M. Bedard, The Symbolism of the Baptismal Font in Early Christian Thought (Washington, DC: Catholic University of America Press, 1951), pp. 1-16.

38 Maj-Brit Wadell, Fons Pietatis: eine ikonographisches Studie (Göteborg: Elanders, 1969), p. 9; Gregory the Great, Comm. in Zacharias, 13.1, in Opera omnia, Patrologiae cursus completus, Series latina, 221 vols (Paris: Garnier, 1844-64), ed. by J.-P. Migne [hereafter $P L$ ], 76 (1857), cols 1039-41.

39 Georg Manz, Ausdrucksformen der lateinischen Liturgiesprache bis ins elfte Jahrhundert (Beuron in Hohenzollern: Beuroner Kunstverlag, 1941), p. 196.

40 Wadell, Fons Pietatis, p. 14; Konrad Burdach, 'Der Gral: Forschungen über seinen Ursprung und seinen Zusammenhang mit der Longinuslegende', Forschungen zur Kirchen-und Geistesgeschichte, 14 (1938), p. 91 (repr. as Der Gral: Forschungen über seinen Ursprung und seinen Zusammenhang mit der Longinuslegende [Darmstadt: Wissenschaftliche Buchgesellschaft, 1974]).

41 Underwood, 'The Fountain of Life', p. 55. 
Christ and purify oneself in the sacrifice in order to rise up as one newly born. ${ }^{42}$

Bernard of Clairvaux (1090-1153) connects the pool of Siloam and Christ in a surprising way. In his Sententiae (III, 119) he writes, 'the waters of Siloam are the recollection and the imitation of the Passion of Christ, so that we should wash ourselves herein and purify ourselves from $\sin .{ }^{33}$ The water of Siloam, he continues, is like the moisture of tears, and the gratia lacrimarum, the gift of tears, is like the inexhaustible stream of Paradise. Bernard compares it to God, who has plunged himself into the Son of Man and taken on the tunic of mortality in order to rise again. In this line of thought, Siloam is drawn into the mystery of the Incarnation. Water becomes the medium of the mystery of mysteries, the very capacity to become human and sacrifice in the flesh.

\section{Sight and Insight}

As noted above, Ambrose in particular emphasized that the man who was born blind refers to the washing away of sins. Moreover, Christ says so in John 9: 'Neither this man nor his parents sinned; he was born blind so that God's works might be revealed in him. ${ }^{44}$ Isidore of Seville (c. 560-633) recognizes in the healing of the blind man the 'healing' of humanity, blinded by the sin of Adam. This healing involves entering into the truth of the Messiah. Darkness gives way to the light of the Lord: 'de tenebris nos vocavit in lumen suum, says Isidore in connection with this passage. ${ }^{45}$ Consequently, blindness is like darkness and sight is akin to light, faith, and truth. ${ }^{46}$

42 Augustine, Opera Omnia, PL, 40 (1861), col. 257.

43 Bernard of Clairvaux, Sententiae, Sancti bernardi Opera, ed. by Jean Leclercq (Rome: Editiones cistercienses, 1974), IV, 1-2, p. 216.

44 Waldemar Deonna and Sabrina Stroppa, Il simbolismo dell'occhio (Turin: Bollati Boringhieri, 2008). In most cultures being born blind is considered a punishment from the gods that can harm the further genealogical line.

45 Isidore of Seville, On Ecclesiastical Duties, in Opera omnia, v, PL, 83 (1850), cols 760-69.

46 For the metaphors sight/faith and blindness/unbelief see also: Dorothy F. Glass, "Then the Eyes of the Blind Shall be Opened”: A Lintel from San Cassiano a Settimo', in Reading Medieval Images: The Art Historian and the Object, ed. by Elizabeth Sears and Thelma K. Thomas (Ann Arbor: University of Michigan Press, 2002), pp. 142-50. The author discusses the iconography of the resurrection of Lazarus within the same opposition. It must be noticed-together with Gertrud Schiller, Ikonographie der christlichen Kunst, 1 (Gütersloh: Mohn, 1966), p. 181-that the healing of the blind man and the resurrection of Lazarus were the most popular
The story of how the blind man was healed conceals deeper metaphors concerning sight and insight. This movement is perceptible in the semantic use of 'to see'. In the Latin Vulgate the words for seeing are all derived from videre, but the manner in which the verba videndi are used in the Greek source text is more nuanced, containing more layers of meaning. Reimund Bieringer analysed the meaning and intensity of words for seeing in John's Gospel. ${ }^{47}$ These verbs of seeing are blepô, noticing; theôreô, 'to observe something with continuity and attention'; and horaô (especially the perfect form, heôraka), 'seeing with the eyes of faith'. They express a seeing that transcends mere physical sight to become seeing with the eyes of faith, thus forming the climax of the pericope. ${ }^{48}$

In the Siloam narrative, all of these variations on 'seeing' are present: blepô (verses 7, 15, 19, 21, 25), the blind person who now sees; theôreô (verse 8), the people see the blind person; anablepo (verses 11, 15, 18), the blind person who sees again; and finally the transcendent heôrakas (verse 37), where Christ reveals himself to the blind man. For the blind person who is healed blepo and anablepô are used, words often associated with the most superficial type of seeing. But blepô is rather surprisingly used in verses 39 and 42 in order to describe insight. Here a sort of 'reader entrapment' ${ }^{\text {'49 }}$ takes place, because in John 9.1-38, the reader learns that blepô in the usual sense of external seeing is used. In the following verses, John 9. 39-42, this is undermined by using the same word to mean figurative seeing: 'I came into this world for judgement so that those who do not see may see, and those who do see may become blind'. That John

miracles until the eleventh or twelfth century. Since early Christian times they had often been represented together on sarcophagi.

47 Reimund Bieringer, “"They have taken away my Lord”: Text-Immanent Repetitions and Variations in John 20. 1-18, in: Repetitions and Variations in the Fourth Gospel: Style, Text, Interpretation, ed. by G. Van Belle, M. Labahn, and P. Maritz, Bibliotheca Ephemeridum theologicarum Lovaniensium, 223 (Leuven: Peeters, 2009), pp. 609-30.

48 Repetitions and Variations in the Fourth Gospel, ed. by Van Belle, Labahn, and Maritz, p. 610; Joost Smit Sibinga, 'Towards Understanding the Composition of John 20', in The Four Gospels 1992: Festschrift Frans Neirynck, ed. by F. Van Segbroeck and others, 3 vols, Bibliotheca Ephemeridum theologicarum Lovaniensium, 100 (Leuven: Leuven University Press, 1992), III, 2139-52 (p. 2139). On the intensity of seeing and its relationship to believing, see G. L. Phillips, 'Faith and Vision in the Fourth Gospel', in Studies in the Fourth Gospel, ed. by F. L. Cross (London: Mowbray, 1957), pp. 83-96 (pp. 91-92).

49 Written communication with Prof. Reimund Bieringer, Biblical Studies, Catholic University of Leuven. 


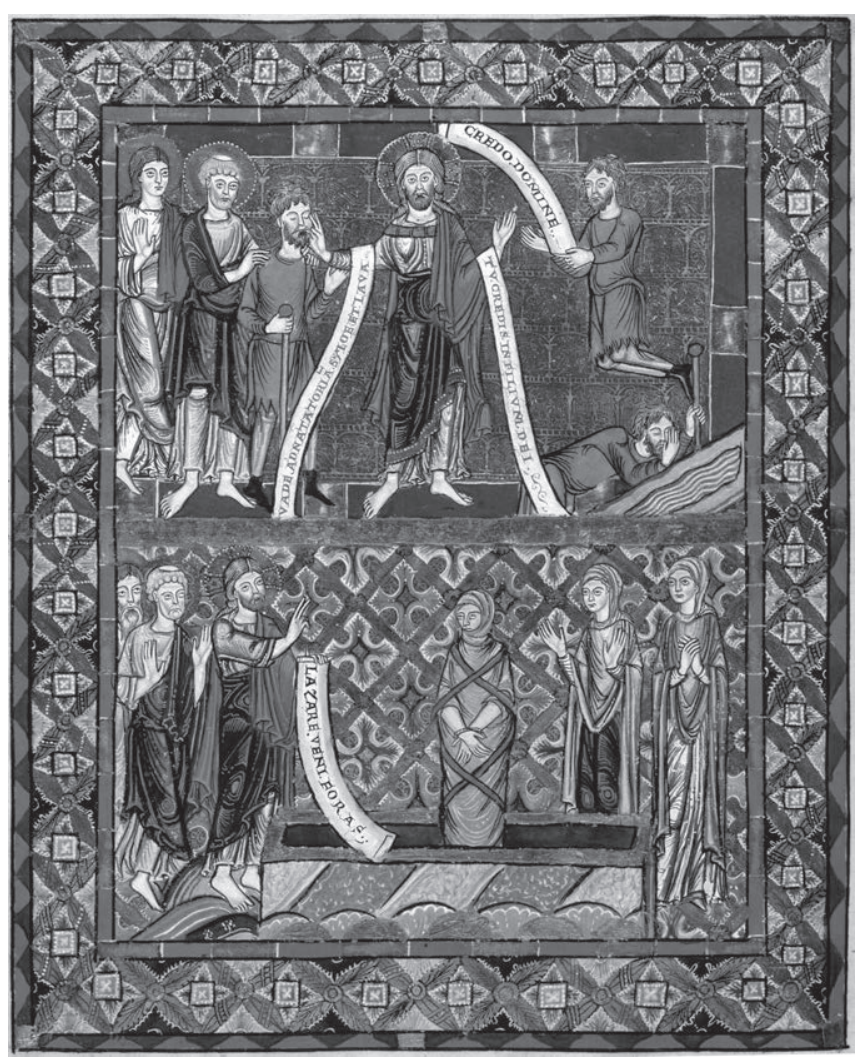

Figure 3.7. Gospels of Henry the Lion, Wolfenbüttel, Herzog August Bibliothek Cod. Guelf. 105 Noviss., fol. 169v, Healing of the Blind Man, with text in banderoles, c. 1175 (photo $\odot$ Wolfenbüttel, Herzog August Bibliothek).

uses anablepô as 'seeing again' is rather strange in connection with a man who was born blind. On the other hand, it can mean seeing again and, as a result, seeing in a different way: seeing the truth and the light of the Messiah. Heôrakas, finally, is placed in Jesus's mouth, when the blind man asks about the Saviour: 'You have seen him, and the one speaking with you is he.' This emphasizes the fact that the miraculous seeing implies the revelation of the Messiah through the 'new' eyes of belief.

Because the miracle of the blind man can be read as the tension between truth and untruth, sight and insight, medieval iconography would soon represent it as the dichotomy between Christian and Jew. The story's ending - the denial of the miracle of sight by the Jewish aldermen and the blind man's next of kin-reinforces anti-Semitism. In the Middle Ages this is seen in the light of the Jews' persistent denial of the Messiah, which was held against them. In the apologetic literature, the blindness of Jews is one of the most notorious topoi; Synagoga wears a blindfold. ${ }^{50}$ In conversion efforts,

50 Bernhard Blumenkranz, Le Juif médiéval au miroir de the summum of the act of conversion is expressed by insight into the truth received through baptism, as in the Wessobrunn Gebetbuch of 814, in which the Jew, Judas Cyriacus, allows himself to be christened after finding the True Cross. ${ }^{51}$

The baptismal font, which was in essence also the fountain of life, becomes in addition a type for Ecclesia. ${ }^{52}$ Numerous allegorical representations of this typology have been preserved. One example is found in the Liber Floridus of Lambert of Saint-Omer (c. 1096-1120). Here Christ crowns Ecclesia, who stands at his right near a baptismal font, while pushing away Synagoga at his left. ${ }^{53}$ The mouth of hell is adjacent to it: as the inscription on the page says, 'Synagoga Christum dei filium abnegans, prophetis incredula, recedens a Deo, corona deposita, vexillo confracto, ad inferum properans' (the Synagogue, denying the Christ son of God, not believing the prophets, distancing herself from God, [is] stripped of her crown, her banner is broken, quickly falls into hell). The opposition between Church and Synagogue was well known in the Middle Ages, on the level of both iconography and the history of ideas. ${ }^{54}$ It became an accepted undercurrent that is also present in the iconography of the blind man at Siloam. In the Gospels of

l'art chrétien (Paris: Études augustiniennes, 1966); Bernhard Blumenkranz, Juifs et Chrétiens dans le monde Occidental, 430-1096 (Paris: Mouton, 1960).

51 Munich, Bayerische Staatsbibliothek, MS Clm 22053, fol. 16 ${ }^{\mathrm{r}}$; Annette von Eckardt and Carl von Kraus, Die Handschrift des Wessobrunner Gebets: Faksimile-Ausgabe (Munich: Kurt Wolff, 1922), pp. 5-22 (p. 5); Katharina Bierbrauer, Die vorkarolingischen und karolingischen Handschriften der Bayerischen Staatsbibliothek (Wiesbaden: Reichert, 1990), pp. 83-84, cat. no. 155; Tafelband, figs 219-336; Marcell Restle, 'In hoc signo vincis: ein Beitrag zur Illustration des Clm 22053', in Per assiduum studium scientiae adipisci margaritam: Festgabe für Ursula Nilgen zum 65. Geburtstag (St Ottilien: EOS, 1997), pp. 27-43; Barbara Baert, A Heritage of Holy Wood: The Legend of the True Cross in Text and Image, Cultures, Beliefs and Traditions: Medieval and Early Modern Peoples, 22 (Leiden: Brill, 2004), pp. 72-80.

52 Underwood, 'The Fountain of Life', p. 37.

53 Ghent, Universiteitsbibliotheek, MS 92, fol. 253 ; Leslie Ann Blacksberg, 'Between Salvation and Damnation: The Role of the Fountain in the Fountain of Life (Madrid: The Prado), in Het wellende water: de bron in tekst en beeld in de middeleeuwse Nederlanden en het Rijnland, ed. by Barbara Baert and Veerle Fraeters, Symbolae Facultatis Litterarum Lovaniensis, Series B, 34 (Leuven: Universitaire Pers, 2005), pp. 157-73 (p. 166); Blumenkranz, Le Juif médiéval, p. 108.

54 See Nina Rowe, The Jew, the Cathedral and the Medieval City: Synagoga and Ecclesia in the Thirteenth Century (Cambridge: Cambridge University Press, 2011). 
Henry the Lion (c. 1175), the scene of the healing of the blind man includes three banderoles with quotations from John 9 that emphasize insight in opposition to the misjudgement of the Messiah by the Jewish community (Fig. 3.7). ${ }^{55}$ The texts say 'Go, wash in the pool of Siloam' (9.7); 'Do you believe in the Son of Man?' (9.35); and 'Lord, I believe' (9.38).

In the thirteenth and fourteenth centuries, the story of the miracle is charged with an anti-Semitic tone. I offer here two examples. ${ }^{56}$ In an Armenian evangeliary of 1262 the theme is presented in its final stage: the blind man shows his regained sight to the Jews. ${ }^{57}$ The miniaturist, T'oros Roslin from Cilicia (southern Turkey), depicts the Jewish family with unpleasant, angry gesticulations and reactions meant to be read as unfaithful. The young man's parents can be discerned among the group, frightened at the way their son has been healed. This fear, a negative emotion, is opposed to the joy experienced in the covenant of salvation. ${ }^{58}$ In the Bulgarian Gospels of Tsar Ivan Alexander of 1356, the apostles and Jews are divided between two scenes; as in the Rossano Gospels, their amazement is depicted as stubborn disbelief.59

55 Wolfenbüttel, Herzog August Bibliothek, MS Guelf. 105 Noviss., fol. 169v' George Swarzenski, 'Aus dem Kunstkreis Heinrichs des Löwen', in Städel Jahrbuch, 7/8 (1932), 241-397 (p. 254 and figs 209, 215, 217-19); Peter F. Ganz and others, Wolfenbütteler Cimelien: das Evangeliar Heinrichs der Löwen in der Herzog August Bibliothek (Weinheim: VCH, Acta Humaniora, 1989).

56 Edward Wheatley, “Blind” Jews and Blind Christians: Metaphorics of Marginalization in Medieval Europe', in Exemplaria, 14.2 (2002), 351-82, in this context offers an interesting contribution to the social consequences of blindness and repudiation. See also Wolfgang S. Seiferth, Synagogue and Church in the Middle Ages: Two Symbols in Art and Literature (New York: Ungar, 1970).

57 Baltimore, Walters Art Museum, MS 539, fol. $358^{\mathrm{r}}$.

58 In Medieval Armenian Culture, ed. by Thomas J. Samuelian and Michael E. Stone, Proceedings of the Third Dr H. Markarian Conference on Armenian Culture (Chico, CA: Scholars Press, 1984), the work of T'oros Roslin is connected to the Crusades. The miniatures by his hand are fully alive with the battle between the three monotheistic religions, which stimulated the formation of negative imagery of Muslims and Jews. See Sirarpie Der Nersessian, 'The Kingdom of Cilician Armenia', in A History of the Crusades, ed. by Kenneth M. Setton, 2 vols (Philadelphia: University of Pennsylvania Press, 1969), II, 630-59; Annemarie Weyl Carr, 'Icon-Tact: Byzantium and the Art of Cilician Armenia', in Treasures in Heaven: Armenian Art, Religion, and Society, Papers delivered at the Pierpont Morgan Library at a symposium organized by Thomas F. Mathews and Roger S. Wieck (New York: Pierpont Morgan Library; Seattle: University of Washington, 1998), pp. 73-102.

59 Turnovo school, scribe known as Simeon; London, British Library, MS Add. 39627, fol. 239' Bogdan D. Filov, Les Miniatures

\section{Seeing and Sending: Beyond Jerusalem}

The way the miracle is described in John's Gospel places Siloam at the centre of symbolic parallels between sin (spot, dirt, mud) and purity (water), between blindness and the receiving of sight, between light and darkness, between revelation through healing and the 'blindness' of the onlookers, and finally between being sent ('him who sent me') and the sending itself ('go, wash'). This last phrase is the hermeneutic key to the episode, for it is contained within the etymology of Siloam itself. It was Augustine who recognized deeper layers for the exegesis of the episode in John. He said that Siloam, and more specifically its toponymic meaning, is exemplary based on its Hebrew etymology from shelach, 'to send'. I paraphrase here:

As for metaphorical signs, any unfamiliar ones that leave the reader puzzled must be examined partly through a knowledge of languages and partly through a knowledge of things. There is a figurative significance and certainly some hidden meaning conveyed by the episode of the pool of Siloam, where the man who had his eyes anointed by the Lord with mud made from spittle was ordered to wash his face. If the evangelist had not explained this name from an unfamiliar language, this important meaning would have remained hidden (verse 57). ${ }^{60}$

Augustine continues:

So, too, many of the Hebrew names not explained by the authors of these books undoubtedly have considerable significance and much help to give in solving the mysteries of the scriptures, if they can be explained at all. ${ }^{61}$

de l'Évangile du roi Jean Alexandre a Londres, Monumenta Artis Bulgariae, 3 (Sofia: Durzhavna pechatnitsa, 1934), p. 53, pl. 115; Ekaterina Dimitrova, The Gospels of Tsar Ivan Alexander (London: British Library, 1994).

60 'In translatis vero signis si qua forte ignota cogunt haerere lectorum, partim linguarum notitia, partim rerum investiganda sunt. Aliquid enim ad similitudinem valet et procul dubio secretum quiddam insinuat Siloa piscina, ubi faciem lavare iussus est cui oculos dominus luto de sputo facto inunxerat. Quod tamen nomen linguae incognitae nisi evangelista interpretatus esset, tam magnus intellectus lateret.' Augustine, De Doctrina Christiana, ed. and trans. by R. P. H. Green (Oxford: Clarendon Press, 1995), pp. 82-83; special thanks to Prof. Thomas O'Loughlin, University of Nottingham.

61 'Sic etiam multa quae ab auctoribus eorundem librorum interpreta non sunt nomina hebraea, non est dubitaandum habere non parvam vim atque adiutorium ad solvenda aenigmata scripturarum, si quis ea possit interpretari.' Augustine, De Doctrina Christiana, ed. and trans. by Green, pp. 82-83. 


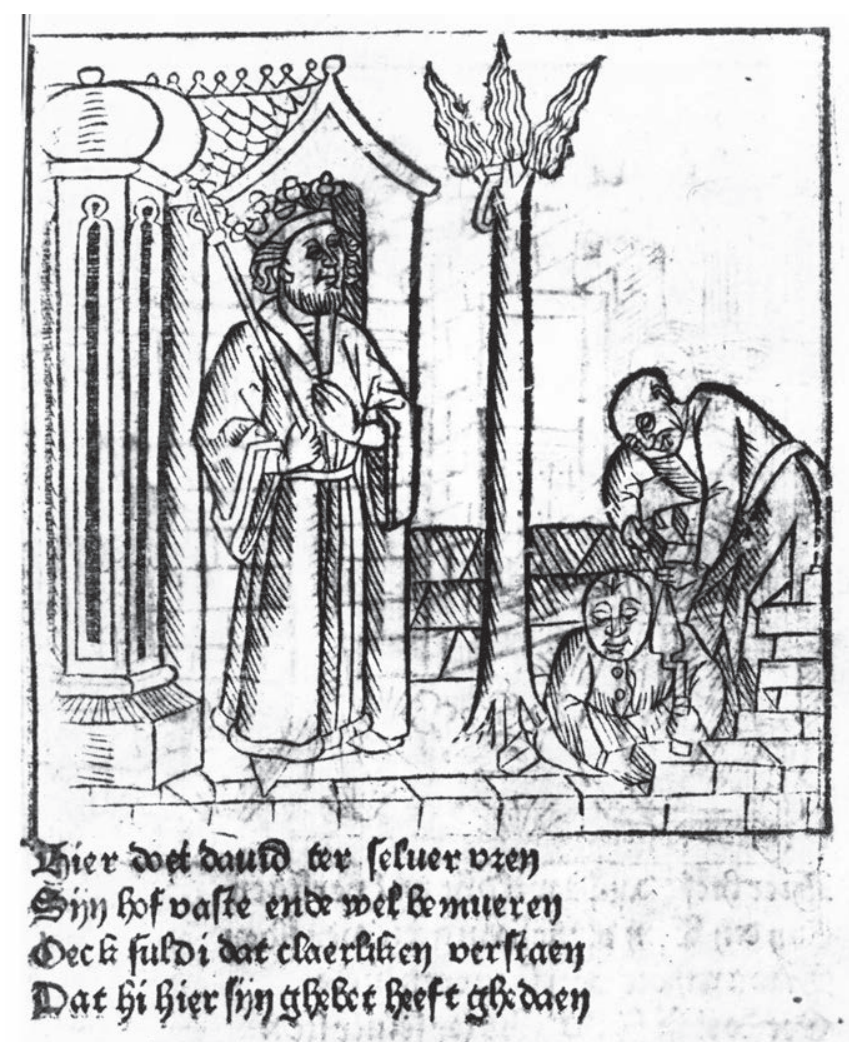

Figure 3.8. Boec van den Houte, incunable printed by Johan Veldener (Culemborg, 1483), Siloam and David

(photo $@$ Brussels, Koninklijke Bibliotheek Albert I).

In short, if the healing of the blind man at Siloam can be reduced to the key concept of 'sending', then the episode must be seen as a process of transformation that takes place between night and day, sand and water, centre and periphery. Through Siloam, the stratification of what it means to be 'sent' and even 'to send' is made explicit on a semantic, physiological, and physical level. Our final challenge is to link these levels of meaning to their importance for Jerusalem studies and the typology of the loca sancta. Let me begin this experiment with a detour.

The water of Siloam is not exclusively associated with the Wirkungsgeschichte of the miracle related in John; it also plays a modest but important role in the legend of the wood of the cross. ${ }^{62}$ The legend arose in the twelfth century and tells the story of the wood from its origins in Paradise to the Crucifixion. As the story goes, when Adam lay dying he sent his son Seth to Paradise for solace. The angel Michael gave Seth three twigs from the tree of life that were later planted on Adam's grave. The tree survived the ravages of time and came into contact with Moses, David, Solomon, and the queen of Sheba,

62 For what follows, see Baert, A Heritage of Holy Wood. up to the time of Christ's Passion. The story offers a narrative and diachronic alternative to other typologies of the tree of life and the cross, between Paradise and Golgotha. ${ }^{63}$ In this version, a new Paradise-alert, mysterious, disguised in a sapling and a block of wood in the Old Testament-patiently stores up the soteriological strength it will release in the messianic sacrifice.

In one of the most extensive versions of the legend of the wood of the cross, the Middle Dutch Van den drie Gaerden (On the Three Twigs) by Jacob van Maerlant (1290-1330), the wood 'passes' the spring of Siloam, according to this medieval source, 'in the time of David'. ${ }^{64}$ David is 'sent' by an angel to collect the twigs of the tree of life, which Moses had planted in the land of Moab, and bring them to Jerusalem. David plants the saplings in his 'garden' and, to his surprise, he discovers the next morning that they are deeply rooted in a spring. Around this spring he will build the city wall. In 1483, the episode with the trees and the wall was illustrated in the incunabulum Boec van den Houte (Book of the Wood), printed by Johan Veldener in Culemborg, which contains several woodcuts that illustrate the tale (Fig. 3.8). ${ }^{65}$

In the legend of the wood of the cross, the spring of Siloam becomes the precise location of Jerusalem's foundation. The legend shows that this locus in the story of salvation must be understood as a key moment. Water and wood become a wall, bound in a single cluster that must explain the 'ur-Jerusalem'. Siloam is still found today in that part of Jerusalem known as the City of David, outside the city walls. This makes Siloam a matrix: the model of the beginning, the germ of a city, of the visual construction 'Jerusalem' in its most archaic natural form-sand, water, stone, growth. The water of Siloam

63 Barbara Baert, 'Adam, Seth and Jerusalem: The Legend of the Wood of the Cross in Medieval Literature and Iconography', in Adam, le premier homme, ed. by Agostino Paravicini Bagliani, Micrologus' Library, 45 (Florence: SISMEL, 2012), pp. 69-99; Barbara Baert, 'Hierotopy, Jerusalem and the Legend of the Wood of the Cross', in Archaeus: Studies in the History of Religions, 11-12 (2007-08), 95-116; Barbara Baert, 'Hierotopy, Jerusalem and the Legend of the Wood of the Cross', in New Jerusalems: Hierotopy and Iconography of Sacred Spaces, ed. by Alexei Lidov (Moscow: Indrik, 2009), pp. 176-201.

64 Dat Boec van den Houte: eine mittelniederländische Dichtung von der Herkunft des Kreuzes Christi, ed. by Lars Hermodsson (Uppsala: Lundequistska, 1959).

65 Barbara Baert, Het 'Boec van den Houte', Verhandelingen van de Koninklijke Academie voor Wetenschappen, Letteren en Schone Kunsten van België, Klasse der Schone Kunsten, 62 (Brussels: AWLSK, 1995). 
that the high priest brings to the Temple during the feast of Tabernacles, the water of Siloam in the Gospel of John that causes the blind man to see, the water of Siloam that contains all our tears and that arrived in a twig from Paradise planted by the hands of David himself-that water of Siloam vibrates in an intuitive epistemology of the boundary between a country and the foundation of a holy city, between nature and culture. And is it not nature itself, and above all water, where the matrix of a locus sanctus arises time and time again? Siloam's meaning is expressed in the figure of David: it is a chosen place, sent from above on a timeline that connects a place with a moment, a chronotopos. Or, as Mircea Eliade (1907-86) so powerfully puts it:

The rocks, springs, caves and woods venerated from the earliest historic times are still, in different forms, held as sacred by Christian communities today. [...] But what the continuity of the sacred places in fact indicates is the autonomy of hierophanies; the sacred expresses itself according to the laws of its own dialectic and this expression comes to man from without. If the 'choice' of his sacred places were left to man himself, then there could be no explanation for this continuity. ${ }^{66}$

66 Mircea Eliade, Patterns in Comparative Religion (New York: Sheed \& Ward, 1958), p. 369. 